\title{
The Challenges of Name Change in South Africa: The Case of Makhado Town
}

\author{
Mavhungu E. Musitha \\ Limpopo Tourism Agency, Polokwane, South Africa \\ Email: mavhungu.musitha@gmail.com
}

Received 23 December 2015; accepted 17 February 2016; published 22 February 2016

Copyright (C) 2016 by author and Scientific Research Publishing Inc.

This work is licensed under the Creative Commons Attribution International License (CC BY). http://creativecommons.org/licenses/by/4.0/

(c) (i) Open Access

\section{Abstract}

This was a descriptive and qualitative case study that investigated the processes involving citizen participation in the course of the attempts to replace the name Louis Trichardt with the name Makhado. I conducted qualitative and descriptive investigation based on data from literature. The data were collated from the literature, i.e. articles, policies, government legislations, municipalreports, attendance registers and reports. The data were collected and captured in excel and analyzed with results shown in tables and figures. In terms of results the study has found that Makhado municipality has widely invited the participation of residents through various platforms. It further revealed that only $6.7 \%$ participated in the renaming process. It was also found that $51 \%$ of residents participated in ward 20 while $49 \%$ participated in ward 21 . Finally, the study concluded by revealing that the majority of the residents did not participate in the consultation process. In conclusion, the study revealed that the majority of the people failed to participate in the renaming process to change the name Louis Trichardt to Makhado. Low participation by residents rendered the proposed name illegitimate. While wards 20 and 21 are predominantly comprised of whites, only a few come out to participate. Low participation by whites suggests that they still want to defend racial identity because the name Louis Trichardt is that of an historical Afrikaans leader. Whites launch court challenges against the new names to protect white names. The study recommends 1) use of the names of people must be prohibited; 2) double-barrel renaming must be encouraged so as to incorporate old names with new names and 3) procedures for name-changing need to be widely publicized so as to ensure that the public is properly informed.

\section{Keywords}

Consultation, Citizen Participation, Makhado Municipality, Chairperson's Association, Social Cohesion 


\section{Introduction}

Consultation processes with the citizens have become key part in the contemporary society as a way of involving them in the affairs that affect their lives. A consultation process can be effective where there is an attempt to promote collaboration that allows active, bi-directional acts of participation, involvement, together with a unification of forces amongst all the role players [1].

Public participation is widely viewed as a crucial component of decision-making by both government and private sector. Globally, it has been recognized as a fundamental component for the achievement of sustainable development and democratic governance. The Rio de Janeiro 1992 and Johannesburg 2002 Earth Summits on Sustainable Development [2] created a foundation for public participation and good governance practices.

Public participation has occupied the public administration arena in recent times as citizens no longer want to see government doing business of service delivery alone. Although, public participation may mean different things to different people, in the Anglo-Saxon tradition it is regarded as an expression of public democracy which is thus seen in terms of active participation in the decision-making processes of government [3]. Unlike the situation in the past where public implementation was the sole responsibility of governments, the twentieth century has ushered in the demand that citizens are expected to participate in the decisions that affect their lives [4].

However, lack of information and knowledge necessary to engage in complex policy matters discourages and intimidates citizens from pursuing active participation [4]. Everyone must be invited to discussion forum meetings as equals and given resources to empower them in direct citizen participation [4]. For example, the results of a study of the public participation in health care decision-making revealed that the public had much to contribute, especially at programme levels, in order to augment the efforts of health care professionals [5].

Participation involves taking part in the process of formulation, and implementation of public policies through involvement of citizens with the aim of influencing decisions that have most probably been taken by public representatives and officials [6]. Governance thus refers to the changing nature of the ways in which public services are provided to society.

Instead of service delivery being left solely in the hands of government, the inter-dependence of all roleplayers is a prerequisite for the provisioning of service delivery (Thornhill, Van Dijk and Ille, 2014) [7]. According to Ngcokovane [8], consultation should be underpinned by an Ideal Model, which he argues is for just and participatory democracy: this suggests that the values of just and participatory democracy in themselves provide a form of governance. Government should thus trust civil society and understand that consultation is not necessarily time-consuming and does not necessarily undermine effectiveness [9].

Following the fall of apartheid and colonialism in 1994 South Africa adopted a democratic constitution which guaranteed all citizens equality before the law. The constitution compels authorities to involve citizens in those affairs that affect their lives (Constitution of Republic of South Africa, 1996) [10]. The same constitution has a chapter on the Bill of Rights which guarantees citizens equal participation in affairs of the country. Section 152 of this constitution compels local government not to undertake any action without involving community structures and stakeholders.

An important goal of the new South Africa is to promote nation-building and social cohesion through the renaming and naming of the country's geographical features: subsequently the parliament passed the South African Geographical Names Council Act of 1998. This Act provides guidelines for the processes of citizen participation that must be followed in the renaming and naming of features.

In 2001, the Greater Louis Trichardt Municipality passed a resolution to change its name to Makhado Municipality. After this resolution had been implemented, the Makhado Municipal council in 2002 resolved also to change the name of the town in which the Makhado Municipality was situated, to Makhado (Makhado Municipal Council, 2002) [11].

Some of the white citizens of the town, Louis Trichardt, opposed the renaming by arguing that there was no need to rename it and that there had been no proper consultations for the change of name. They claimed that this was an attempt to replace an Afrikaner's name (i.e. Louis Trichardt) with the name of a former Vhavenda king. They approached the Supreme Court, which ruled against them when the judge said that there was enough evidence of opportunities for consultations and that in fact there was not even any need for such consultations. But they were not to be discouraged and took the case to the Supreme Court of Appeal which found in their favour, thus setting aside the name, Makhado. 
Makhado is a name of the Vhavenda King who defeated the Voortrekkers in the 1880s, when they trekked into his land, where the town of Louis Trichardt is now situated. According to the Limpopo Premier, Mr. Sello Moloto (cited in Thotse, 2010) [12] “The history of the struggle against colonialism is marked by Makhado's heroic contribution".

In this paper I investigate the processes involving citizen participation in the course of the attempts to replace the name Louis Trichardt with the name Makhado. Furthermore I provide recommended strategies for the conducting of future renaming processes in South Africa.

\section{Material and Methods}

\subsection{Location of the Study Area}

The two wards (20 and 21) which are the study areas are part of the 37 wards in the Makhado municipality which is found in Limpopo province of South Africa. They were picked because they were the only wards which were formally white before blacks moved into this community of whites only.

The choice of these wards for this study was to establish the popularity of the new names proposed since whites are only found in these two wards. These two wards are almost equally represented by different racial groups. The wards were previously white dominated until after 1994 when other racial groups also began settling in these wards. The other 35 wards are predominantly black. The name Louis Trichardt could be expected to receive overwhelming support in these two wards, compared to the rest of the 35 predominantly black constituencies. The results of the nomination of the other black dominated wards are available and shown in the study but this study focuses only on wards 20 and 21.

\subsection{Study Design}

This is a qualitative and descriptive case study employed secondary sources.

\subsection{Data Collection Method}

The data were collated from the literature, i.e. articles, policies, government legislations, municipal-meeting resolutions, attendance registers and reports. Reports submitted by the South African Geographical National Council (SAGNC) to the Minister of the National Department of Arts and Culture are assessed.

\subsection{Data Analysis}

The data were collated from the literature, articles, policies, government legislations, municipal reports, attendance registers and reports. The data were collected captured in excel and analyzed with results shown in tables and figures representing the findings of the study.

\section{Previous Studies on Renaming of Features}

\subsection{Europe}

Renaming of features is not limited to Africa only. In 330 A.D. Constantine the Great (r. 306-337) (26.229), moved the ancient imperial capital from Rome to the city of Byzantium which was located on the easternmost part of the European continent, at a major intersection of east-west trade. The emperor Constantinople renamed this ancient port city Constantinople ("the city of Constantine") after himself [13].

Belgium: Deux-Nèthes $\rightarrow$ Antwerpen (1815); Dyle $\rightarrow$ Zuid-Brabant (1815) (First change); Escaut $\rightarrow$ OostVlaanderen (1815); Henegouwen $\rightarrow$ Hainaut (1830) (Second change). Canada: Newfoundland $\rightarrow$ Newfoundland and Labrador (2001); Upper Canada -> Canada West -> Canada ->Ontario; Lower Canada -> Canada East -> Canada ->Quebec [14].

\subsection{Zimbabwe}

Zimbabwe which was a British colony began the process of renaming its features to reflect itself. Snodia, Tasara and Nicholas [15] in their studies argued that Zimbabwe embarked on renaming of features in order to deconstruct the colonial legacy. However, they revealed that the legacy of colonialism is still there and a lot still needs 
to be done for Zimbabwe to reflect its true black heritage.

The other study conducted by Chabata [16] cited in Chabata [17] argues that the reason colonialists imposed the names on Zimbabwean features was to commemorate their leaders and places in Europe and Britain. They imposed their colonial names on towns, cities, roads, schools, and residential suburbs. The name given to the country was Rhodesia, named after the British mining magnate, Cecil John Rhodes.

The other names imposed were Salisbury; Fort Victoria; Umtali; Queque and Fort Victoria to mention a few. When Zimbabwe became independent, its new government began the process of reversing the colonial names via a process of renaming and replaced them with the names of their own heroes and heroines, dead and alive.

The name of the country Rhodesia was the first to change when it was renamed Zimbabwe. Salisbury was renamed Harare; Victoria became Masvingo; Gwelo became Gweru; Sinoia became Chinhoyi; Umtali was renamed Mutare, to mention but a few [17].

The study by Snodia, Muguti and Mutami [18] argues that colonialists or settlers renamed features in Zimbabwe in order to acquire full authority over the land.

Language and cultural imperialism were employed to remind indigenous people that they had now become subjects of Britain. Renaming and naming was a way of confirming the conquest of the indigenous people and signaling the emergence of a new authority that introduces a new identity for the newly conquered country (Mushati, 2013) [19]. In order to entrench their authority over the whole of Zimbabwe, colonialists showed disdain for local or indigenous names and culture as they associated these names with pagan backwardness (Snodia, Muguti and Mutami, 2010) [18].

All Africans were given English names called "çhristian names" and forced to speak English in order to enjoy some of the "benefits" afforded by the colonialists such as going to school or getting birth certificates, thus ensuring that African culture was destroyed step by step [20].

The renaming and naming of infrastructure and places was a tool of consolidation of "white hegemony in the country" and also represented the British heritage with names such as Cecil John Rhodes; Queen Victoria; Salisbury; Jameson; Churchill; Queen Elizabeth; King George; Wilson; Grey; Stanley [18].

\subsection{Botswana}

In Botswana, there have been attempts at renaming some of the towns and streets with British influenced names, in order to give a sense of identity and ensure greater relevance to the country.

The mayor of Francistown has tabled a motion for the review of street s names in the Central Business District. The motion was accepted by the Francistown City Council in 2013.

The pattern of renaming is similar to that of Zimbabwe and probably that of South Africa in which naming is about the honouring of indigenous heroes and heroines [21]. The renaming in Botswana is also aimed at reclaiming its African identity [21].

The Local Government Act (2012) grants the authority to districts, towns and city councils to rename streets in their areas of jurisdiction after appropriate consultation processes (Botswana Local Government Act, 2012) [22].

\subsection{South Africa}

In South Africa which is the study area of this study, the study by (Coombes 2004) [23] cited in Guyot and Seethal (2007) [24] asserts that the new names that are brought in to replace those of the past are symbols for rectifying or clearing distorted memories of the past. According to the authors, many place names in South Africa are symbols of racial identity [24].

The opposition experienced in South Africa against name changes is along the lines of race and ethnicity since many of the existing names are the products of colonialism, racial appropriation, segregation and apartheid (Guyot and Seethal, 2007) [24]. The National Place Name Committee (NPNC) that was formed in 1939 to conduct consultations on name changes, concentrated on Afrikaans and English names but changed to Afrikaans names from 1948 to reflect the political power dominant at the time (Jenkins, 1990) [25].

However, dual bilingual names became common, with names such as Cape Town and Kaapstad; East London and Oos Londen; Richards Bay and Richardsbaai [24]. The authors have found that whites will defend a place name to preserve their identity, roots and symbols while black Africans want to legitimize the new political dispensation by honouring both their living and dead heroes: some white people however have contrasting views 
[24]..

While Coombes [23] argues that renaming is about rectifying or clearing the memory of the past, Ndletyana [24] sees the renaming as a restoration of indigenous memory processes. Ndletyana corroborates the findings by Guyot and Seethal [24] in arguing that renaming will depend on how South Africa's Black population recalls its indigenous memories Ndletyana (2012). The author also leaves it to Black people as to whether they would like to either challenge or retain the colonial memory. Ndletyana [26] supports the argument by Guyot and Seethal [24]. that some whites will defend certain existing place names as he argues that they will form organised groups to challenge the renaming process in courts, and strive to reverse the renaming, due to the "insufficient" consultation process.

The renaming cases often revolve around procedural flaws [26]. The struggle for the defense of racial names and its consequences is aptly captured by (Sengani, 2011) [27] as follows:

The Makhado-Louis Trichardt renaming saga has now become a battleground for two opposing forces, the government on the one hand, and the so-called Hlanganani/Chairperson's group on the other hand, with each name getting toppled by the other before the ink for its endorsement has even dried.

\section{Citizen Participation in the Renaming Process in South Africa}

South African Geographical Names Committee (SAGNC) facilitates the transformation process for geographical names in order to promote awareness of the economic and social benefits of the standardisation of geographical names. SAGNC therefore sets standards and guidelines for local and provincial authorities in their own areas. The council also receives proposed geographical names submitted by State departments, statutory bodies, provincial governments, municipalities, or individuals.

In addition, it recommends geographical names to the Minister for approval (SAGNC, 1998) [28]. The SAGNC is required to operate within the framework of the constitution which dedicates a Chapter to a Bill of Rights: Chapter 10 gives the values and principles of public administration in South Africa which direct that there must be transparency, fairness and openness in executing any action.

"The Promotion of Administrative Justice Act 3 of 2000, as amended" gives effect to the right to administrative action that is lawful, reasonable and procedurally fair, and to the right to demand written reasons for administrative action, as outlined in section 33 of the Constitution of the Republic of South Africa, 1996.

Section 3(1) dictates that administrative action, which materially and adversely affects the rights or legitimate expectations of any person must be procedurally fair. Sub-section 2(b)(i) provides that for such action to be procedurally fair, adequate notice of the nature and purpose of the proposed administrative action should be issued. Section 6(1) provides that any person who is not satisfied with the administrative action may institute proceedings in a court or a tribunal for a judicial review.

South Africa, as a new democracy and in the quest for promoting social cohesion, in aiming to safeguard people's right to reclaim their heritage, has agreed to change some names [29]. The occupation of African countries including Zimbabwe was characterized by depersonalization and dehumanization of the African people. However, the greatest blow was land dispossession, plundering and cultural dislocation of their mentality [30].

\section{The Makhado Citizen Participation in Consultation Process}

In 2007, the South Africa Court of Appeal ruled against Makhado as the new name for the town of Louis Trichardt on the basis that there had been mo proper consultation was not done.

The court ruling became media headline news, e.g. in the Vhembe Herald Newspaper of April [31]. ("Consult or ...?”). The same newspaper also carried the following comment: "a local authority must consult properly with the citizens when planning the name-change of a town" [32]. Makhado Municipality resolved at its council meetings to re-start the renaming process by conducting "proper consultations". This round of consultations started in 2007. The Naming Committee identified 167 consultative venues across the municipal area.

Before the consultation process was rolled out there was a workshop facilitated by the PGNC which resolved that consultation process records of attendance at meetings should be kept. The Makhado Municipal Name Committee was responsible for facilitating the consultation process by this time providing for sufficient consultation with the residents of the municipality on the proposed name change. This followed the Supreme Court of 
Appeal of South Africa's earlier decision to set aside the Gazetted name of Makhado- on the basis that insufficient consultations had taken place. Instead of appealing the judgment, the Makhado Municipality chose to restart the process afresh. Invitations were issued in English, Afrikaans, Tshivenda, Xitsonga and Northern Sotho.

\section{Presentation of the Findings}

The process of consultations began with advertising for residents to participate in the name-changing process. The advertising was made on various platforms. Figure 1 below shows the platforms for the consultation process.

Figure 2 below shows the suggested names from which the name with the majority of votes would be submitted to the municipal name committee for its approval. Figure 2 shows the total number of the suggested names at consultative meetings in the wards of Makhado Municipality that were consolidated by the municipal names committee. The percentages of votes each name received from the participants in those meetings are shown. Those names with the highest number of votes would be recommended to the municipal council meeting who would then pass a resolution on the recommended names to forward to the National Geographical Names Council (NGNC) who would provide quality assurances, and advise the Minister of Arts and Culture who would approve, or disapprove of the proposed name-change.

Figure 3 below illustrates the consultation process for Ward 20. The total number of the participants in the consultative process was 303. The second and third names proposed were Louis Trichardt and Swongozwi respectively.

Figure 4 below shows the statistics for the residents in ward 21. The total number of the participants in the

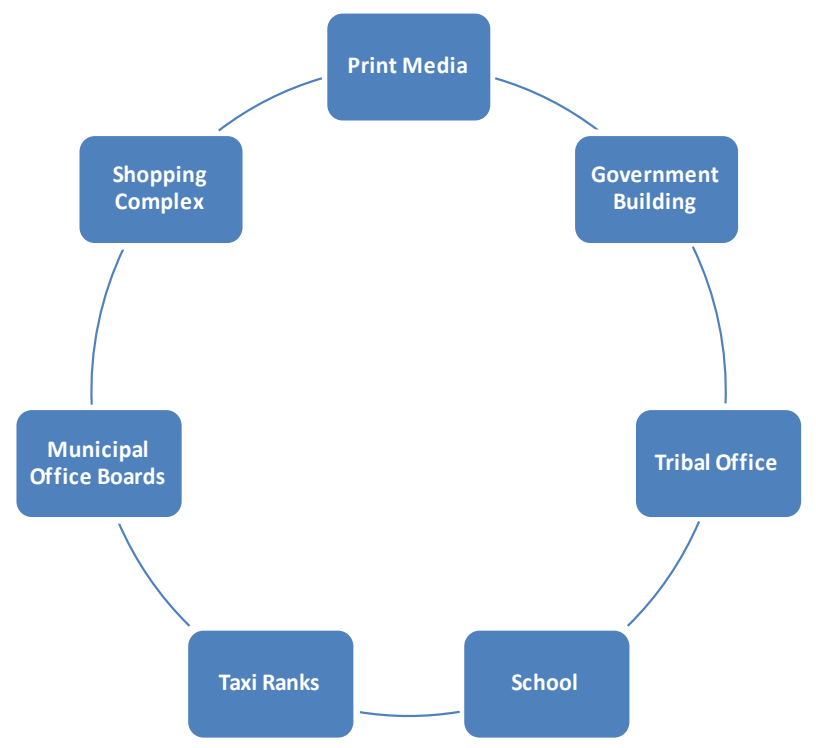

Figure 1. Platforms for consultation process.

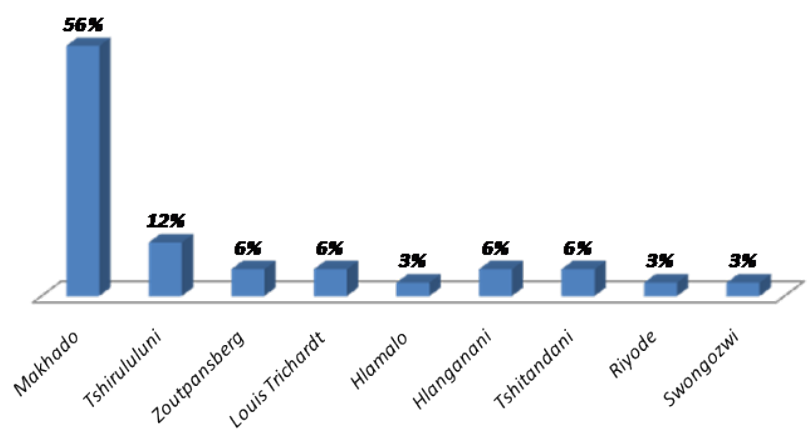

Figure 2. Suggested names. 


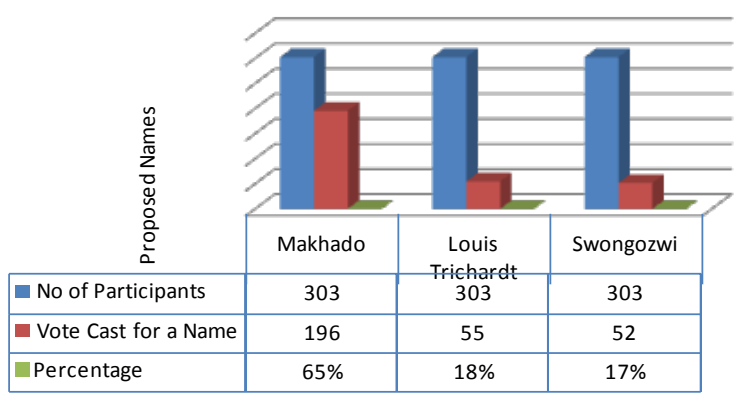

Figure 3. Consultation process in ward 20.

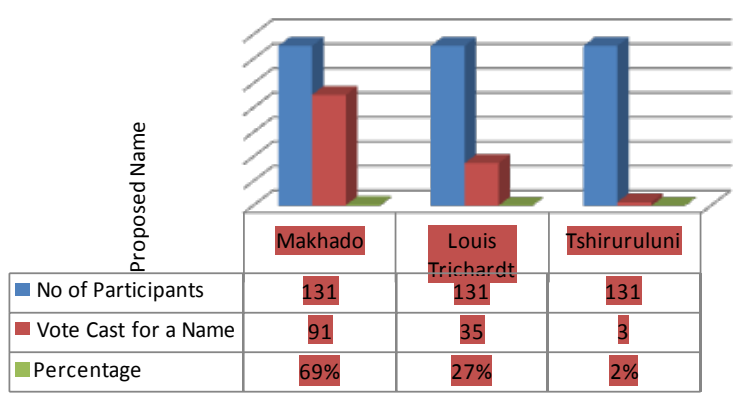

Figure 4. Consultation process in ward 21.

consultative process was 131. The second and third names were Louis Trichardt and Tshirululuni, respectively. This suggests that the name with the highest percentage votes therefore be recommended to become the new name of the town.

Figure 5 below presents a summary of the total percentage of votes cast for each name as proposed by the participants in the consultative meetings. The name that has the highest percentage from the consultative meetings is the one that is recommended to become the new name for the town- and in this case, it should therefore, replace the existing name of Louis Trichardt.

Figure 5 shows the four names shortlisted from the many that were proposed at various consultative meetings. The four names are shown with the total number of percentage votes and the percentages cast for each of them. From the figures above the name, it can be seen that Makhado has the highest percentage votes. This, therefore, suggests that Makhado will be recommended to become the new name for the town. The second name is Tshirululuni, which might also be recommended - in the event that Makhado is not finally supported by the municipal council meeting that pronounces on the adopted name to be sent to the Minister to be gazetted. Louis Trichardt and Zoutpansberg will also follow in that order, in case the name of Tshirululuni is not supported in the municipal-council meeting. Therefore, in relation to Figure 3 and Figure 4, Figure 6 below provides the number of whites and blacks who participated in wards 20 .

\section{Discussions}

\subsection{Provisioning of Information}

Innes and Booher [33] argue that participation should be a multi-way interaction in order to reach common goals-but most importantly participants must be afforded a voice [34].

In order to ensure that participants received the information about the planned consultation process, Makhado Municipality advertised venues for the consultation sessions. Figure 1 shows all the platforms which were used to disseminate information to the citizens of the municipality for this consultation process. It also wanted to ensure that the citizens could participate and make inputs.

This is consistent with the findings by Arnstein [35] and Vigoda [1], who argues that consultations should go beyond mere public hearings: instead they should promote meaningful participation by allowing inputs from the citizens. This view is also corroborated by Ngcovane (1968) [8] who points out that consultation gives rise to 


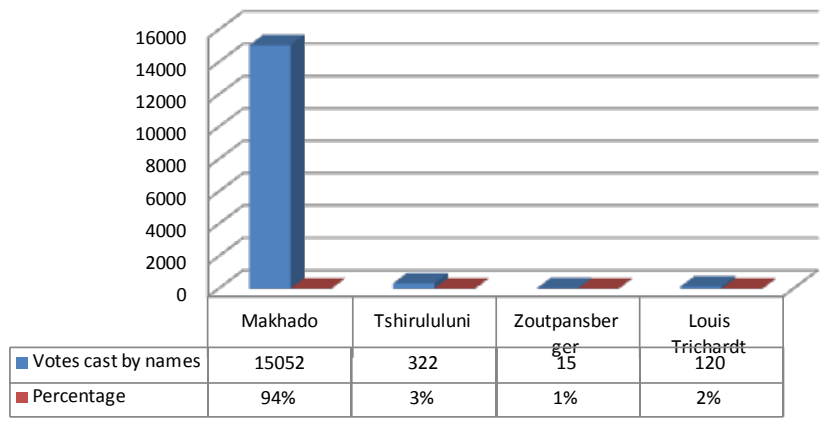

Figure 5. Summary of votes.

Ward 20

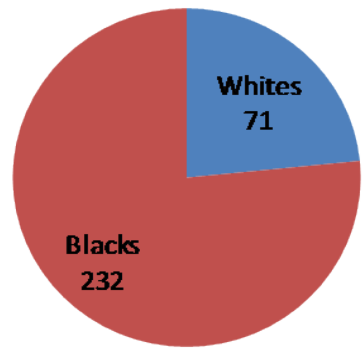

Ward 21

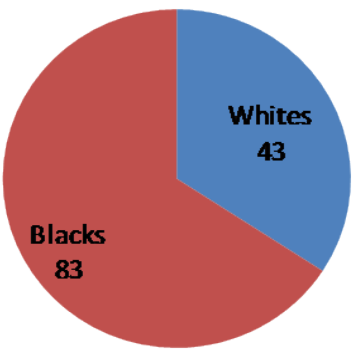

Figure 6. Number of whites and blacks who participated in consultation process in ward 20and Ward 21.

participatory democracy and that it offers an opportunity for stakeholders and citizens to participate in planning and decision-making.

\subsection{Legitimacy}

Citizen participation promotes legitimacy for decisions to be implemented by the authorities. Participation of citizens leads to ownership of decisions and planning so that the citizens refrain from rejecting official decisions. In the words of Abelson and Gauvin (2006) [36] and Lowry (2013) [37] "legitimacy increases the degree of accountability and ownership". In Figure 2, total percentages of votes cast in the whole municipality of 37 wards are indicated the participants' support for the names suggested in the consultative forums.

Those names came from the participants themselves who decided which names to propose: the names were not forced on them by the government officials. This approach is consistent with the findings of Connor (1988) [38] who found that consultation is a way of soliciting a solution from the participants, unlike those proposed or imposed by government or by government officials.

The proposed names are the product of intense engagement by the residents. However, the name Makhado which scored the highest percentage received 56\% (see Figure 2).

While Figure 3 and Figure 4 show that consultation processes occurred in wards 20 and 21, the statistics shows small percentage of participation. For example, in Ward 20 with a population of 20508, only 51\% participated in the consultation process, with the name Makhado receiving 65\%, followed by Louis Trichardt receiving $18 \%$ and lastly Tshirululuni with $17 \%$. Figure 4 shows that in Ward 21 only $49 \%$ of residents participated in the consultation process, with the name Makhado receiving 69\%, followed by Louis Trichardt with 27\% and Tshirululuni with $2 \%$.

Figure 5 shows the total number of residents in the whole of Makhado municipality who participated in the consultative process. However, only a very small number of citizens participated in the process. The total number of registered Makhado residents as reflected in the voters 'roll is 232,300.

While the name Makhado received $94 \%$ of the total votes (15052) cast, this however, represents only $6.5 \%$ of the total population of Makhado municipality- which is 232,300 as reflected on the electoral voters' roll. This is 
also, despite the fact that 167 venues across the municipal area were identified for meetings so as to make it easier for the residents to participate. Thus to reiterate as shown in Figure 5, only 155,509 participants participated in consultative processes, i.e. a mere percentage of $6.7 \%$.

\subsection{Resistance to Renaming Process}

Figure 3 and Figure 4 showed that in wards 20 and 21, where it would have been assumed that the Whites would come out in large numbers since they are mainly concentrated in these two wards, very few actually turned up for the consultation process.

The name Louis Trichardt only managed 35 votes in ward 21; while in ward 20, only 55 votes were cast for the name. This is $0.1 \%$ in ward 21 while in ward 20 it is $0.3 \%$ which suggests a sign of resistance or defending of the existing racial name [24] [26]. However a court challenge is to be approached with a claim that people were not consulted and that consultation was not properly conducted [26].

\subsection{Resistance to Renaming Process}

While it has been argued that governance is promoted by the participation of civil society in planning, the results of this study do not confirm this. This is in contradiction to the findings of Arnstein [35] and Castle and Culver [39] who all assert that consultation promotes participatory democracy.

Generally, the figures suggest that the majority of the residents did not have any interest in the name-change process; otherwise, they would surely have come out in larger numbers to reclaim their heritage. This is confirmed by the small percentage that turned out for the name change consultations.

This might also suggest that the majority do not understand the impact of colonialism on Africa, as argued by Rodney [29]. Castle and Culver [39] found that consultations could only enhance democracy if the preferences of the citizens are accommodated in determining their decisions.

This small percentage suggests that residents may not have confidence in the municipal processes or feel that they are being used to rubber stamp government decisions, particularly if whites in this ward feel that their memory is to be erased [23].

These findings may also indicate that most people feel they have far more important issues to contend with e.g basic survival and may lack time, lack knowledge and skills for effective participation [40]-[43].

\section{Recommendations Flowing from This Study}

\subsection{Naming after the People}

It is recommended that henceforth naming and renaming should not include people whether living or dead.

Naming after the people has the potential to polarise the nation because it has to do with removing names of certain groups and replacing them with names of another group: this is a point emerging from the study by Chabata [17] who says that when Zimbabwe became independent, it began the process of reversing the colonial names by renaming them and replaced them with heroes and heroines dead and alive.

This way of renaming will be viewed as erasing the memory of the past of other groups, i.e. in this case, the whites since they are the ones who imposed their names and values during their rule [23]. According to Snodia, Tasara and Nicholas [15] the whites destroyed the values and heritage of indigenous people: they argue that Zimbabwe embarked on renaming of features in order to "deconstruct the colonial legacy".

When Zimbabwe became independent, its government began the process of reversing the colonial names by renaming them and replacing them with names of heroes and heroines dead and alive. The name of the country Rhodesia was the first to fall and renamed Zimbabwe. Salisbury was renamed Harare; Victoria became Masvingo; Gwelo became Gweru; Sinoia became Chinhoyi; Umtali renamed Mutare; to mention but a few (Chabata 2012) [17].

Some argue that place names are symbols of racial identity (Guyot and Seethal, 2007) and as such renaming is done because of racial and ethnicity demands, since the existing names are a product of colonialism, racial appropriation, segregation and apartheid (Guyot and Seethal, 2007) [24]. According to them whites will defend names against the perceived black names aimed at legitimising a new political dispensation in order to preserve their identity [24].

Resistance to renaming may be regarded as a symbol of defeat since it echoes the same method used by colo- 
nialist and apartheid leaders to show their superiority over the defeated indigenous people. According to Ndletyana [26] one of the strategies whites will use to defend their identity will be through the formation of organised groups to challenge decisions in courts and present cases of insufficient, improper or lack of consultation.

\subsection{Double-Barrel Names}

Double-barrel naming is seen as a possible solution to allay the fears of those who feel that their history is being erased by those who want to legitimise the new dispensation. This strategy does not seek to define categories of heroes but recognises all leaders unlike the Zimbabwean example which has shown that renaming seeks to commemorate heroes and heroines whether dead or alive by reversing colonial names (Chabata, 2012) [17].

It must be clear that the apartheid government was led exclusively by a group of racist whites while freedom fighters were mainly blacks who fought to replace apartheid with democracy. Therefore new South Africans now choose to characterize the new dispensation as a constitutional multi-democracy.

In a double-barrel situation, there are no losers or winners. A double-barrel compromise was experienced before in South Africa between English and Afrikaner groups. Towns and cities carried two names and anyone might choose between the two versions as to what to call them. For example, Cape Town was also called Kaap Stad; East London = Oos Londen; Richards Bay = Richards Baai, etc. The same should happen even today with the inclusion of the new proposed names. In the case of Louis Trichardt and Makhado the new name could be Louis Trichardt-Makhado or Louis Trichardt $=$ Makhado. The direction maps should also reflect the names as such.

In this case all sides are winners and everybody's interests are catered for and this will help to minimise racial and ethnic tensions.

Double-barrel renaming might bring some sense of satisfaction in relation to restoration of heritage as renaming is also a tool to reclaiming of African identity [21]. Some argue that this identity was destroyed when colonialists imposed their names, as for example on Zimbabwean features to commemorate their leaders and places in Europe and Britain [16] cited in (Chabata, 2012) [17]. Sengani feels that colonialists renamed areas because they felt that it was their right since they defeated those who occupied it (Sengani, 2011) [27].

To avoid a perpetual situation of warring conflicts where renaming places becomes a battlefield Sengani (2011) this study strongly recommends a double-barrel renaming process.

\subsection{Education}

Educating of people is the only way to empower them and develop people with skills to participate meaningfully in any engagement. Therefore, local government should empower citizens to enable them to participate in local governance (Edwards, 2013) [44].

There are some who criticise the consultation process because they argue that participants lack time, knowledge and skills for effective participation [40]-[43]. Education and training of participants will also move them from the bottom rung of non-participation [35].

They will also be empowered to step up onto the middle rug though it is characterized by tokenism and then upper rung which offers more meaningful empowerment and participation. The old saying that knowledge is power will be realized in this way and participants will understand their roles and responsibilities when government invites them to participate in meaningful. In other words they need to understand what a citizen's role embraces.

\section{Conclusions}

This study has found that while Makhado municipality had issued notices via a number of platforms inviting the residents to participate in renaming processes, the majority of the people failed to participate. Thus participation by only a minority of the residents rendered the proposed name illegitimate because the majority did not take part in the process. The study also found that while wards 20 and 21 were predominantly comprised of whites, only a few came out to participate.

This low participation by whites suggests that they still want to defend racial identity because the name Louis Trichardt is that of an historical Afrikaans leader. They might feel that it is their memory that the new dispensation is targeting via replacement with black names. This is an indication that they would use it to launch a court challenge against the new name and racial tensions would keep on simmering. In order to manage renaming 
processes, this study therefore recommends that naming places after people should be avoided because someone's leader might be someone's enemy. Government should move towards double-barrel renaming so that the two names could co-exist and be used together.

The general low turnout for consultation might suggest that the residents do not understand the importance of naming and renaming and in order to address this, training and education should be embarked upon to empower them and also to encourage them to initiate the process themselves.

\section{Acknowledgements}

The author acknowledges Prof. Andre Lemmer for professionally editing this study. The author also acknowledges Mrs. Phuti Maloma for analyzing data and producing graphs for this study.

\section{References}

[1] Vigoda, E. (2002) From Responsiveness to Collaboration: Governance, Citizens, and the Next Generation of Public Administration. Public Administration Review, 62, 527-540. http://dx.doi.org/10.1111/1540-6210.00235

[2] United Nations (2002) World Summit on Sustainable Development. 24 August to 4 September, Johannesburg.

[3] Webler, T. and Renn, O. (1995) A Brief Primer on Participation: Philosophy and Practice. In: Renn, O., Webler, T. and Wiedemann, P., Eds., Fairness and Competence in Citizen Participation: Evaluating Models for Environmental Discourse, Vol. 10, Kluver Academic Publishers, Dordrecht, 17-33.

[4] Roberts, N. (2004) Public Deliberation in an Age of Direct Citizen Participation. American Review of Public Administration, 34, 315-353.

[5] Litva, A., Coast, J., Donovan, J., Eyles, J., Shepherd, M., Tacchi, J., Abelson, J. and Morgan, K.. (2002) The Public Is Too Subjective: Public Involvement at Different Levels of Health Care Decision Making. Social Science and Medicine, 54, 1825-1837. http://dx.doi.org/10.1016/S0277-9536(01)00151-4

[6] Parry, G., Moysera, G. and Day, N. (1992) Political Participation and Democracy in Britain. Cambridge University Press, Cambridge. http://dx.doi.org/10.1017/cbo9780511558726

[7] Thornhill, C., Van Dijk, G. and Ille, I., Eds. (2014) Public Administration and Management in South Africa: A Developmental Perspective. Oxford University Press, Cape Town.

[8] Ngcokovane, C. (1989) Demons of Apartheid: A Moral and Ethical analysis of the NGK, NP, and Broederbond's Justification of Apartheid. Skotaville Publishers, Braamfontein.

[9] King, C.S. and Stivers, C. (1988) Government Is Us: Public Administration in an Anti-Government Era. Sage Publications, London.

[10] Republic of South Africa (1996) Constitution of the Republic of South Africa (Act 108 of 1996). Government Printer, Pretoria.

[11] Municipality, M. (2009) Submission of Reports on Name Change for Louis Trichardt Town to Makhado to Provincial Geographical Names Committee.

[12] Thotse, M. (2010) Contesting Names and Statues: Battles over the Louis Trichardt/Makhado “City-Text” in Limpopo Province, South Africa. Kronos, 36, 173-183.

[13] Brooks, S. (2009) Byzantium (ca. 330-1453). Heilbrunn Timeline of Art History. The Metropolitan Museum of Art, New York. http://www.metmuseum.org/toah/hd/byza/hd byza.htm

[14] Wikipedia, the free encyclopedia (2015) Geographical Renaming.

[15] Snodia, M., Tasara, M. and Nicholas, M. (2014) Deconstructing the Colonial Legacy through the Naming Process in Independent Zimbabwe. Journal of Studies in Social Sciences, 6, 71-85.

[16] Chabata, E. (2007) The Role of Place-Names in the Making of a Zimbabwean Identity. Nytt om namn, 46, 13-17.

[17] Chabata, E. (2012) Names and Identities: Feature Names and Identity in Zimbabwe. Oslo Studies in Language, 4, 4559. http://www.journals.ulo.no/osla

[18] Snodia, M., Muguti, T. and Mutami, N. (2010) Political Dialoguing through the Naming Process: The Case of Colonial Zimbabwe (1890-1980). The Journal of Pan African Studies, 3, 16-30.

[19] Mushati, A. (2013) Street Naming as Author(iz)ing the Collective Memory of the Nation: Masvingo's Mucheke Suburb in Zimbabwe. International Journal of Asian Social Science, 3, 69-91. http://www.aessweb.com/journal-detail.php?id=5005

[20] Wa Thiongo, N. (1986) Decolonising the Mind: The Politics of Language in African Literature. Heinemann, Portsmouth. 
[21] Manatsha, B.T. (2014) The Politics of Renaming “Colonial” Streets in Francistown, Botswana. Historia, 59, $269-288$.

[22] Republic of Botswana (2012) The Local Government Act. The Government Printer, Gaborone.

[23] Coombes, A.E. (2004) Visual Culture and Public Memory in a Democratic South Africa. Wits University Press, Johannesburg.

[24] Guyot, S. and Seethal, C. (2007) Identity of Place, Places of Identities, Change of Place Names in Post-Apartheid South Africa. The South African Geographical Journal, 89, 55-63. http://dx.doi.org/10.1080/03736245.2007.9713873

[25] Jenkins, E. (1990) From Leliefontein to Megawatt Park: Some Trends in the Naming of South African Places. English Academy Review, 7, 60-67. http://dx.doi.org/10.1080/10131759085310071

[26] Ndletyana, M. (2012) Changing Place Names in Post-Apartheid South Africa. Social Dynamics: A Journal of African Studies, 38, 87-103. http://dx.doi.org/10.1080/02533952.2012.698949

[27] Sengani, T.M. (2011) Voice Interplay in the Makhado-Louis Trichardt Renaming Saga. Southern African Journal for Folklore Studies, 21, 175-185.

[28] Republic of South Africa (1998) South African Geographical Names Council (Act 118 of 1998). Government Gazette.

[29] Rodney, W. (1972) How Europe Underdeveloped Africa. East African Educational Publishers, Dar es Salaam.

[30] Ncube, B., Dhlamini, N. and Moyo, T. (2013) The Philosophy of Naming among the Ndebele of Zimbabwe. A Study of Children’s Names Born between 1970-1982. International Journal of Asian Social Science, 3, 1725-1731.

[31] Vhembe Herald, 18 April 2007, Vhembe.

[32] Vhembe Herald, 21 September 2007, Vhembe.

[33] Innes, J. and Booher, D.E. (2004) Reframing Public Participation: Strategies for the 21st Century. Planning Theory and Practice, 5, 419-436. http://dx.doi.org/10.1080/1464935042000293170

[34] Graham, J., Bruce, A. and Plumtree, T. (2003) Principles for Good Governance in the 21st Century. Institute on Governance, Ottawa.

[35] Arnstein, S.R. (1969) A Ladder of Citizen Participation. Journal of the American Institute of Planners, 35, 216-224. http://dx.doi.org/10.1080/01944366908977225

[36] Abelson, J. and Gauvin, F. (2006) Assessing the Impacts of Public Participation: Concepts, Evidence and Policy Implications. Research Report/06 Public Involvement Network. http://www.cpm.org

[37] Lowry, A.L. (2013) Achieving Justice through Public Participation: Measuring the Effectiveness of New York’s Enhanced Public Participation Plan for Environmental Justice Communities. MA Dissertation, Paper 180.

[38] Connor, D.M. (1988) A New Ladder of Citizen Participation. National Civic Review, 77, 249-257. http://dx.doi.org/10.1002/ncr.4100770309

[39] Castle, D. and Culver, K. (2006) Public Engagement, Public Consultation, Innovation and the Market. The Integrated Assessment Journal: Bridging Sciences and Policy, 6, 137-152.

[40] Berman, E. (1997) Dealing with Cynical Citizens. Public Administration Review, 57, 105-112. http://dx.doi.org/10.2307/977058

[41] Irvin, R. and Stansbury, J. (2004) Citizen Participation in Decision Making: Is It Worth the Effort? Public Administration Review, 64, 55-65. http://dx.doi.org/10.1111/j.1540-6210.2004.00346.x

[42] Schooley, S. (2008) Appreciative Democracy: The Feasibility of Using Appreciative Inquiry at the Local Government Level by Public Administrators to Increase Citizen Participation. Public Administration Quarterly, 32, 243-281.

[43] Yang, K. and Callahan, K. (2007) Citizen Involvement Efforts and Bureaucratic Responsiveness: Participatory Values, Stakeholder Pressures, and Administrative Practicality. Public Administration Review, 67, 249-264. http://dx.doi.org/10.1111/j.1540-6210.2007.00711.x

[44] Edwards, V.A. (2013) Theory of Participation for 21st Governance. International Journal of Organisation Theory and Behavior, 16, 1-28. 